\title{
Setting, Speaking, and Framing in the News Discourse of Elected Executions: A Play in Three Acts
}

\author{
C. Lee Harrington, Heather Reece, Glenn W. Muschert
}

\section{Introduction}

This manuscript takes a dramaturgical approach to the study of elected executions (hereafter EEs), or the not-uncommon cases in which those sentenced to death take legal steps to hasten their own executions. In a prior manuscript based on nearly 30 years of national (Associated Press) news coverage of EEs, we identified two dominant frames used by print news journalists in this context, choice and competency, and explored the frames' impact on inmates' decision-making processes and on public perception of EEs (Muschert, Harrington and Reece 2009). In this manuscript we draw on the same data set to examine the more nuanced question of how journalists establish broader cultural authority over EEs through their narrative constructions of the phenomenon. That is, by linking various social actors to various social settings when employing different frames in news reporting, what larger story or drama are journalists telling about EEs? Our approach extends recent scholarship that (re)-introduces issues of power and politics into capital punishment debates (see Culver 1999; Jacobs and Carmichael 2002; Jacobs and Kent 2007; Kubik and Moran 2003; Langbein 1999) and into framing research (Carragee and Roefs 2004) by addressing a question at the informal political level - how cultural authority over EEs is established through routine journalistic practices. We begin by summarizing recent developments in the status of capital punishment in the US, including the phenomenon of EEs, followed by a review of the relevant scholarly literature that helps contextualize our research.

\section{Capital Punishment in the US}

The status of capital punishment in the US has undergone significant transition in the past decade. While the average number of executions per year was higher between the years 2000-2007 ( $\mathrm{n}=5$ ) than between 1973-1999 $(n=3.1)$, the number of death sentences per year has dropped dramatically since 1999. For example, the 111 death sentences imposed in 2008 were the lowest since reinstatement of capital punishment in 1976 and represented a 63\% decline over the past decade (Death Penalty Information Center, http://www.deathpenaltyinfo.org/documents/ FactSheet.pdf, accessed January 4, 2010). Reasons for declining executions are myriad, including the economic cost of the death penalty in the context of a global recession (Grinberg 2009), lingering concerns about the lethal injection process (Associated Press November 14, 2009), lack of empirical support for the death penalty's deterrence effect (Kovandzic, Vieraitis and Boots 2009), and continuing questions of innocence (Dieter 2009). The 2006 Gallup Poll found that only $65 \%$ of Americans support the death penalty, down from a high of $80 \%$ in 1994, and when offered the choice of life without parole instead of the death penalty only $47 \%$ support the death penalty.

Our focus is on death row inmates who elect to hasten their own execution, an under-studied and underpublicized aspect of the larger national debate over capital punishment. There were 133 "successful" cases of EEs in the US between 1976 and 2009, representing 11\% of the total population of executed inmates (DPIC, http:// www.deathpenaltyinfo.org/documents/FactSheet.pdf, accessed January 4, 2010). While some might view EEs as 
unproblematic, simply the accelerated imposition of a pre-determined sentence, there is a lively debate in the sociolegal literature over their legal and ethical implications. Since executions are typically hastened through inmates' decisions to waive final (habeas) appeals, a major area of concern is the actual voluntariness of such decisions given deplorable conditions on death row (e.g. Strafer 1983), concomitant concern about inmates' mental health status (e.g. Blume 2005), and related questions about the reliability of competence assessment instruments (e.g. Nicholson and Norwood 2000).[1] Additional areas of concern include the implications of transforming an adversarial legal process into a consensual or cooperative one (e.g. Dieter 1990) and the appropriate duties of mental health professionals and defense counsel in this unusual legal context (e.g. Harrington 2000; Wallace 1992). As noted, our interest is in how EEs are framed by the media (our prior study), and how framing practices help establish broader cultural authority over the phenomenon of EEs (our present study).

Below we review two discourses on capital punishment that help inform this project, followed by a discussion of dramaturgical (constructionist) approaches to social problems. Given space restrictions, both discussions are necessarily brief.

\section{Scholarly Discourses about Capital Punishment}

The first relevant discourse focuses on the death penalty, politics, and the policy-making process. Nearly 15 years ago Dieter warned that the "political promotion of capital punishment by those responsible for interpreting and implementing the law interferes with the right to a fair hearing and increases the likelihood that innocent defendants will be executed" (1996: 1-2). Focusing on the relationship between appointed and elected judiciary and death determinations, Dieter cautions that "the infusion of the death penalty into political races is reaching new extremes and distorting the criminal justice system" (1996: 1). Other scholars writing in this tradition include: Culver (1999), who focuses on state-level intra-institutional conflict that impacts death penalty policy-making (see also Langbein 1999); Jacobs and Carmichael (2002), who explore the social and political forces that make capital punishment legal in some jurisdictions but not others; Kubik and Moran (2003), who examine the impact of gubernatorial politics on the execution stage; and Jacobs and Kent, who find that "national level Republican strength [and] presidential elections that emphasize law and order" increase yearly executions (2007: 297).

In the context of EEs, questions of informal political influence are raised by multiple scholars including Bonnie who suggests that "the death penalty is unique not only in its severity as a punishment but also in its tendency to distort the roles played by all participants in the process" (1990: 69), and Harrington (2004), who explores how mutual distrust between the prosecution and the defense might impact courts' determination of inmate competency to waive final appeals and proceed to execution. In short, the capital punishment literature suggests that all stages of capital cases, from sentencing to execution, are subject to political influences both formal and informal. Our interest in how cultural authority over EEs is established through journalistic practices furthers knowledge on informal political influences on capital punishment.

A second relevant scholarly discourse focuses on capital punishment and the media, which is a surprisingly underdeveloped research area given that most of us know what we know about capital punishment from media sources rather than first-hand. Most extant research focuses on the media's impact on homicide deterrence (e.g. Jacoby et al. 2008; Stack 2007). Additional research areas include the news media's role in normalizing executions for the public (e.g. Greer 2006; Lipschultz and Hilt 1999; Niven 2004), the role of fictionalized entertainment programming in capital punishment debates (Sarat 2001; Wardle and Gans-Boriskin 2004), and the relationship between news content and public support for the death penalty (e.g. Fan, Keltner and Wyatt 2002). Of most relevance to this manuscript is our own prior study of how EEs are framed by US print news media (Muschert et al. 2009). Drawing on the data set described below, we found that journalists' construction of two binary frames (choice and competency) fits "dominant norms of news construction" in that "binary concepts almost without exception have moral power, which gives them both a resonance with the mass public and a sustaining news value" (Coe et. al, 2004: 235, 237; see also Greer 2006). These binary frames are consistent with the socio-legal literature which tends to discuss EEs through a dominant discourse of volunteering (suggesting a positive framing of EEs) and a minority discourse of suicide (suggesting a negative framing of EEs; Harrington 2000). In terms of the larger national debate on capital punishment, a volunteering/choice frame tends to support the inmate's desire for swift execution, thus aligning with pro-death penalty activists, while a suicide/competence frame tends to question the inmate's intentions and/or mental health, thus aligning with death penalty abolitionists (Harrington 2000, 2004; Muschert, et al 2009). Here, we go beyond this analysis to consider journalists' selection of frames in the context of both setting and speaking, with 
interest in how these practices help establish broader cultural authority over EEs.

\section{The Dramaturgy of Executions: A Constructionist Approach to Framing}

Our project also draws on the small body of literature that takes a dramaturgical approach to social issues. Drawing on Erving Goffman's (1959) seminal work on the ongoing, interactional construction of social meaning(s) through everyday performance, the dramaturgical literature explores ritualistic dimensions of social problems and/ or social movements. As Benford and Hunt (1992) explain, "social movements can be described as dramas in which protagonists and antagonists compete to affect audiences' interpretations of power relations in a variety of domains" (1992: 38). Viewing contested events as dramas allows the researcher to focus on the constituent parts, including the cast of characters and the stages on which they interact. In the context of capital punishment, Lofland (1975) utilized the dramaturgical approach to compare historical (open) executions with modern (closed) ones (see Foucault [1977] for a discussion of the pre-modern performance of capital punishment). More recently, Miller and Hunt (2008) build on Lofland through examination of $500+$ newspaper reports, suggesting that "[e]xecutions are the final act in a series of dramatic events" that include discovery of the crime, the criminal investigation, the trial, the appeals, and the final execution (2008: 189). Focusing on newspaper announcements as the "denouement" of executions, the authors find that "the construction of the majority of execution stories implies that the death sentence is a proper closure to a string of criminal and legal events" (2008: 208). In general, they conclude that little has changed about the dramaturgy of executions since Lofland's 25-year-old study (2008: 209; see also Conquergood 2002).

Miller and Hunt eliminated cases of EEs from their database to avoid outliers though they suggest that a comparison with EEs is warranted (2008: 209). Furthermore, the socio-legal framing of inmates who elect executions as volunteers is itself intriguing in that it re-casts the clear antagonist in the drama of capital punishment - the convicted criminal - as a would-be protagonist instead, proceeding willingly to his or her death (we return to this point later). While our data was collected prior to the publication of Miller and Hunt's article and thus is not a direct reply to their suggested research agenda, we believe our findings can help deepen scholars' understanding of how the rituals of EEs (as framed by journalists) are shaped by larger cultural narratives of capital punishment.

In journalism, one often hears about the axiomatic five-W's: who, what, where, when, why, and how. One element of a drama that is crucial to understanding the context in which events and speech occur is to set the stage by specifying the location. Meaning is conveyed within the context of its physical and social settings, something noted by ethnomethodological (e.g. Eglin 1980; Eglin and Hester 2003: 19-21) and dramaturgical (e.g. Benford 1992) scholars. As journalists select settings for the stories they tell, they are in fact offering a type of context for the meanings of the actions and dialogues they describe. Indeed, scholars in mass communication have acknowledged the importance of settings in news discourse, particularly as selection of settings can convey something about where the story takes place, and thus whom it impacts and concerns (Chyi and McCombs 2004; Muschert and Carr 2006). Analytical attention to the settings of news stories may help identify the "where" axiomatic in journalistic practice. Journalists' selection of setting may in fact reflect an underlying schema related to how they interpret the events they report upon. Once a setting is established, "story characters appear on cue" (Eglin and Hester, 2003: 13-27; Sacks 1992: 254), including protagonist(s) and antagonist(s) as journalists select participants to act and speak in their reportage. Identifying the speakers (and combinations of speakers) selected by journalists to discuss various aspects of EEs may help to identify the "who" axiomatic in journalism.

Knowing who speaks (and where) ultimately allows us to consider how cultural authority over EEs is constructed via print news sources and how that construction might change over time as an inmate discursively journeys from crime to execution. Benford and Hunt (1992) suggest that dramaturgical frameworks in a social movement context serve to construct and communicate various interpretations of power: "What is it? Who has it? Who doesn't? How is it wielded? Who ought to have it? How should it be used?" (1992: 37). Furthermore, media framing itself does not occur in a political or power vacuum (Carragee and Roefs 2004: 215) and is particularly crucial to explore in the context of capital punishment since, as noted earlier, it is the only source of knowledge about the topic for most of us. In this manuscript, we explore the changing cast of characters that journalistically tell the story of EEs in the US. Following the spirit of the dramaturgical approach, we present our findings in the form of a three-act play, returning in the conclusion to larger considerations about power and cultural authority in this unusual legal context. We emphasize that our study is limited to a content (textual) analysis of US print news media - we do not have empirical data on journalists' intentions or readers' interpretations.

We note that a dramaturgical approach is wholly consistent with a sociological (constructionist) approach to 
framing. We are mindful of Van Gorp's recent article pointing to the vague usage of framing terminology in scholarly writings - "In a way, frames seem to be everywhere, but no one knows where exactly they begin and where they end" (2007: 62). We follow his approach, rooted in Goffman, that a frame is "an invitation or incentive to read a news story in a particular way" (2007: 63), that frames manifest themselves through "word choice, metaphors, exemplars, descriptions, arguments, and visual images" (2007: 64), that framing is a dynamic process subject to negotiation (2007: 64), that frames are a form of metacommunication with their own logic and meaning (2007: 65), and that "a frame that is applicable only to one particular issue [such as elected executions], in fact is preferably linked to another, more abstract 'master' frame [such as capital punishment]" (2007: 67). We return to this point in the conclusion.

\section{Method}

To understand journalists' selection of settings and speakers in the discourse of EEs, we identified all cases of EEs occurring between 1977 and 2006 listed on the Death Penalty Information Center's website, as illustrated in Table 1.

Table 1. Elected Executions by US States

\begin{tabular}{|c|c|c|c|c|c|}
\hline State & $\begin{array}{l}\text { Year of Legal } \\
\text { Reinstatement }\end{array}$ & $\begin{array}{l}\text { Year of First } \\
\text { Execution }\end{array}$ & $\begin{array}{l}\text { Executions since } \\
\text { Reinstatement }\end{array}$ & $\begin{array}{l}\text { Elected Executions since } \\
\text { Reinstatement }\end{array}$ & $\begin{array}{l}\text { Rate of Elected } \\
\text { Executions }\end{array}$ \\
\hline $\mathrm{AK}$ & Not Reinstated & & & & \\
\hline $\mathrm{AL}$ & 1976 & 1983 & 34 & 4 & $11 \%$ \\
\hline $\mathrm{AR}$ & 1973 & 1990 & 27 & 4 & $15 \% 5 \%$ \\
\hline $\mathrm{AZ}$ & 1973 & 1992 & 22 & 3 & $14 \%$ \\
\hline CA & 1973 & 1992 & 13 & 2 & $15 \%$ \\
\hline $\mathrm{CO}$ & 1977 & 1997 & 1 & 0 & $0 \%$ \\
\hline $\mathrm{CT}^{*}$ & 1973 & 2005 & 1 & 1 & $100 \%$ \\
\hline $\mathrm{DE}^{*}$ & 1974 & 1992 & 14 & 4 & $29 \%$ \\
\hline FL & 1972 & 1979 & 60 & 9 & $14 \%$ \\
\hline GA & 1973 & 1983 & 39 & 0 & $0 \%$ \\
\hline $\mathrm{HI}$ & Not Reinstated & & & & \\
\hline IA & Not Reinstated & & & & \\
\hline $\mathrm{ID}^{*}$ & 1973 & 1994 & 1 & 1 & $100 \%$ \\
\hline $\mathrm{IL}^{*}$ & 1974 & 1990 & 12 & 2 & $17 \%$ \\
\hline $\mathrm{IN}^{*}$ & 1973 & 1981 & 17 & 5 & $29 \%$ \\
\hline KS & 1994 & $\mathrm{n} / \mathrm{a}$ & 0 & & \\
\hline $\mathbf{K Y}$ & 1975 & 1997 & 2 & 1 & $50 \%$ \\
\hline LA & 1973 & 1983 & 27 & 0 & $0 \%$ \\
\hline MA & Not Reinstated & & & & \\
\hline $\mathrm{MD}^{*}$ & 1975 & 1994 & 5 & 1 & $20 \%$ \\
\hline $\mathrm{ME}$ & Not Reinstated & & & & \\
\hline MI & Not Reinstated & & & & \\
\hline MN & Not Reinstated & & & & \\
\hline $\mathrm{MO}$ & 1975 & 1989 & 66 & 4 & $6 \%$ \\
\hline MS & 1974 & 1983 & 7 & 0 & $0 \%$ \\
\hline MT & 1974 & 1995 & 3 & 1 & $33 \%$ \\
\hline $\mathrm{NC}$ & 1977 & 1984 & 43 & 4 & $9 \%$ \\
\hline
\end{tabular}




\begin{tabular}{|c|c|c|c|c|c|}
\hline ND & Not Reinstated & & & & \\
\hline $\mathrm{NE}$ & 1973 & 1994 & 3 & 0 & $0 \%$ \\
\hline $\mathrm{NH}$ & 1991 & $\mathrm{n} / \mathrm{a}$ & 0 & & \\
\hline $\mathrm{NJ}$ & 1982 & $\mathrm{n} / \mathrm{a}$ & 0 & & \\
\hline $\mathrm{NM}^{*}$ & 1979 & 2001 & 1 & 1 & $100 \%$ \\
\hline $\mathrm{NV}^{*}$ & 1973 & 1979 & 12 & 10 & $83 \%$ \\
\hline NY & 1995 & $\mathrm{n} / \mathrm{a}$ & 0 & & \\
\hline $\mathrm{OH}^{*}$ & 1974 & 1999 & 23 & 6 & $25 \%$ \\
\hline OK & 1973 & 1990 & 81 & 7 & $8 \%$ \\
\hline $\mathrm{OR}^{*}$ & 1978 & 1996 & 2 & 2 & $100 \%$ \\
\hline $\mathrm{PA}^{*}$ & 1974 & 1995 & 3 & 3 & $100 \%$ \\
\hline RI & Not Reinstated & & & & \\
\hline SC & 1974 & 1985 & 36 & 7 & $19 \%$ \\
\hline SD & 1979 & $\mathrm{n} / \mathrm{a}$ & 0 & & \\
\hline $\mathrm{TN}$ & 1974 & 2000 & 2 & 0 & $0 \%$ \\
\hline $\mathbf{T X}$ & 1974 & 1982 & 374 & 25 & $7 \%$ \\
\hline $\mathrm{UT}^{*}$ & 1973 & 1977 & 6 & 4 & $67 \%$ \\
\hline $\mathrm{VA}^{*}$ & 1975 & 1982 & 97 & 8 & $8 \%$ \\
\hline VT & Not Reinstated & & & & \\
\hline $\mathrm{WA}^{*}$ & 1975 & 1993 & 4 & 3 & $75 \%$ \\
\hline WI & Not Reinstated & & & & \\
\hline WV & Not Reinstated & & & & \\
\hline WY & 1977 & 1992 & 1 & 0 & $0 \%$ \\
\hline
\end{tabular}

Source: Death Penalty Information Center, www.deathpenaltyinfo.org, accessed August 27, 2006.

Note: States examined in the present study are boldface.

*States in which the first execution after lift of moratorium was elected by the inmate.

By examining all cases of EEs in six states, the study identified a sub-set of cases representative of the 26 states that have carried out EEs. Selection criteria for states including identifying those with high rates of execution (Florida, Nevada, and Texas), those who resumed executions in both earlier and later decades (Florida, Nevada, and Texas vs. Kentucky, New Mexico, and Ohio), states whose first-in-jurisdiction execution was elected (Nevada, New Mexico, and Ohio), states with high rates of EEs (Nevada and New Mexico), and states from various regions of the country (two from the West, one from the Midwest, and three from the South). In all, the study examines 52 of the 125 EEs in six US states between 1979 and 2006, as illustrated in Table 2.

Table 2. Inmates Who Elected Execution in Selected States

\begin{tabular}{|l|l|l|l|l|l|l|}
\hline Inmate & Year Sentenced & Year Executed & Race/ Ethnicity & Gender & AP Articles & $\begin{array}{l}\text { Articles } \\
\text { about EEs }\end{array}$ \\
\hline TEXAS & & & & & & \\
\hline Stephen Peter Morin & 1981 & 1985 & W & M & 13 & 11 \\
\hline Charles Rumbaugh & 1975 & 1985 & W & M & 15 & 15 \\
\hline Jeffrey Allen Barney & 1981 & 1986 & W & M & 0 & 0 \\
\hline Ramon Hernandez & 1980 & 1987 & L & M & 0 & 0 \\
\hline Elisio Moreno & 1983 & 1987 & L & M & 0 & 0 \\
\hline
\end{tabular}




\begin{tabular}{|c|c|c|c|c|c|c|}
\hline Jerome Butler & 1986 & 1990 & B & M & 5 & 4 \\
\hline James Smith & 1983 & 1990 & B & M & 4 & 3 \\
\hline Anthony Cook & 1988 & 1993 & W & $\mathrm{M}$ & 2 & 2 \\
\hline Richard Lee Beavers & 1986 & 1994 & W & M & 4 & 4 \\
\hline George Lott & 1992 & 1994 & W & M & 14 & 3 \\
\hline Esequel Banda & 1995 & 1995 & $\mathrm{~L}$ & M & 2 & 2 \\
\hline Leo Jenkins & 1988 & 1996 & W & M & 6 & 3 \\
\hline Joe Gonzales & 1992 & 1996 & $\mathrm{~L}$ & $\mathrm{M}$ & 2 & 2 \\
\hline Richard Brimage Jr. & 1988 & 1997 & W & M & 3 & 3 \\
\hline Benjamin Stone & 1980 & 1997 & W & M & 4 & 4 \\
\hline Steven Renfro & 1996 & 1998 & W & $\mathrm{M}$ & 7 & 7 \\
\hline Aaron Foust & 1997 & 1999 & W & $\mathrm{M}$ & 0 & 0 \\
\hline Charles Tuttle & 1995 & 1999 & W & M & 1 & 1 \\
\hline Richard Wayne Smith & 1992 & 1999 & W & M & 13 & 10 \\
\hline Robert Atworth & 1996 & 1999 & W & M & 4 & 2 \\
\hline Larry Hayes & 1999 & 2003 & W & $\mathrm{M}$ & 0 & 0 \\
\hline Ynobe Matthews & 2000 & 2003 & B & M & 7 & 7 \\
\hline Peter Miniel & 1986 & 2004 & $\mathrm{~L}$ & M & 10 & 9 \\
\hline James Porter & 2000 & 2005 & W & M & 13 & 13 \\
\hline Alexander Martinez & 2001 & 2005 & $\mathrm{~L}$ & M & 10 & 10 \\
\hline \multicolumn{7}{|l|}{ NEVADA } \\
\hline Jesse Bishop & 1977 & 1979 & $\mathrm{~W}$ & $\mathrm{M}$ & 68 & 57 \\
\hline Carroll Cole & 1981 & 1985 & W & M & 0 & 0 \\
\hline William Paul Thompson & 1989 & 1989 & $\mathrm{~W}$ & M & 5 & 5 \\
\hline Sean Patrick Flannagan & 1987 & 1989 & $\mathrm{~W}$ & $\mathrm{M}$ & 0 & 0 \\
\hline Thomas Baal & 1988 & 1990 & W & $\mathrm{M}$ & 9 & 9 \\
\hline Roderick Abeyta & 1989 & 1998 & $\mathrm{~L}$ & M & 9 & 7 \\
\hline Sebastian Bridges & 1998 & 2001 & W & M & 17 & 15 \\
\hline Lawrence Colwell Jr. & 1995 & 2004 & W & $\mathrm{M}$ & 25 & 23 \\
\hline Terry Jess Dennis & 1999 & 2004 & $\mathrm{~W}$ & $\mathrm{M}$ & 21 & 19 \\
\hline Daryl Mack & 2002 & 2006 & B & $\mathrm{M}$ & 21 & 16 \\
\hline \multicolumn{7}{|l|}{ FLORIDA } \\
\hline Michael Durocher & 1983 & 1993 & W & $\mathrm{M}$ & 0 & 0 \\
\hline Dan Hauser & 1996 & 2000 & W & $\mathrm{M}$ & 7 & 7 \\
\hline Edward Castro & 1988 & 2000 & $\mathrm{~L}$ & $\mathrm{M}$ & 12 & 11 \\
\hline Rigoberto Sanchez-Velasco & 1988 & 2002 & $\mathrm{~L}$ & M & 29 & 29 \\
\hline Aileen Wournos & 1992 & 2002 & W & $\mathrm{F}$ & 120 & 77 \\
\hline Newton Slawson & 1990 & 2003 & W & $\mathrm{M}$ & 7 & 6 \\
\hline Paul Hill & 1994 & 2003 & W & $\mathrm{M}$ & 197 & 53 \\
\hline John Blackwelder & 1983 & 2004 & W & M & 25 & 21 \\
\hline Glen Ocha & 2000 & 2005 & W & M & 6 & 6 \\
\hline \multicolumn{7}{|l|}{ OHIO } \\
\hline Wilford Berry & 1986 & 1999 & W & $\mathrm{M}$ & 73 & 58 \\
\hline Stephen Vrable & 1989 & 2004 & W & M & 22 & 22 \\
\hline Scott Mink & 2001 & 2004 & W & M & 14 & 12 \\
\hline
\end{tabular}




\begin{tabular}{|c|c|c|c|c|c|c|}
\hline Herman Dale Ashworth & 1996 & 2005 & W & M & 20 & 19 \\
\hline Rocky Barton & 2003 & 2006 & $\mathrm{~W}$ & M & 15 & 12 \\
\hline Darrell Ferguson & 2003 & 2006 & W & M & 14 & 11 \\
\hline \multicolumn{7}{|l|}{ KENTUCKY } \\
\hline Edward Lee Harper & 1982 & 1999 & W & $\mathrm{M}$ & 21 & 20 \\
\hline \multicolumn{7}{|l|}{ NEW MEXICO } \\
\hline Terry Clark & $1987 / 1996$ & 2001 & W & M & 182 & 120 \\
\hline
\end{tabular}

Source: Death Penalty Information Center, www.deathpenaltyinfo.org/executions.php, accessed August 27, 2006.

The data were comprised of articles from the Associated Press (AP), which receives reports from 1,500 papers throughout the United States and serves 121 countries (Associated Press, n.d.), and is a source for stories through the regional, national and, international lenses. Articles were identified using keyword searches of the LexisNexis database by the full name of each inmate, limited to the time frame from the start of the year of conviction through one month following execution. In all, 942 articles were identified, and these were culled to retain the 749 documents discussing EEs. The data includes only those inmates whose efforts to hasten execution were successful, as no database systematically tracks inmates who indicate a desire for swift execution but later change their minds or those who are found mentally incompetent to proceed to execution.

Coding follows the ethnographic content analysis approach advocated by Altheide $(1987,1996)$. The unit of analysis is the article and the full text of each article was examined numerous times during the coding process. Through immersion in the data (Glaser and Strauss 1967), we identified major thematic elements in the news discourse (van Dijk, 1988). To ensure inter-coder reliability, we conducted tests using Scott's $\pi$, a statistic which controls for intercoder agreement likely to occur by chance (Scott 1955). Pre-tests and post-tests of coding reliability indicated highly reliable coding along a variety of continua, as follows: whether articles were problematic/non-problematic (pre-tests observed $42.2 \%$ inter-coder agreement, $\pi$-value 0.80 , while post-tests returned inter-coder agreement of $97.8 \%$, $\pi$-value 0.93 ); and along locations dimensions(pretests observed agreement of $65.0 \%, \pi$-value 0.58 , while post-tests returned agreement of $98.0 \%, \pi$-value 0.98 ). Along the speakers dimension, the pretest returned an agreement of $56.9 \%$, and the post-test returned an inter-coder agreement of $97.7 \%$, the non-discrete coding with which cannot be assessed in terms of Scott's $\pi$.

We first identified whether articles were problematic or contested, when the issue of inmates' electing executions is questioned and treated as non-routine, or not problematic, when nothing in the article raises concerns about inmates' electing execution. Of the 749 articles about EEs, 341 (45.5\%) discussed EEs as problematic while 408 $(54.5 \%)$ treated EEs as non-problematic. We further identified the settings and speakers selected by journalists as they write about EEs. The setting is the scene where the action takes place and coding along this dimension was discrete. The speakers are those selected by the journalists to speak directly or in paraphrase. A speaker is defined by their dominant role. Categories for speaker were non-discrete in that articles could include more than one speaker. However, coding was discrete in the sense that a single speaker can only belong to a single speaker type. A word of caution is warranted: the examination of news reportage allow us to understand those settings and characters selected by journalists as they write about EE, and we are unable to make reliable statements about who actually participates in the discourse surrounding EEs. Rather, we reliably identify narrative elements that journalists covering the events deem important.

\section{Findings}

\section{Setting and Speaking about Elected Executions}

Our analysis identifies the primary settings and speakers selected by journalists as they write about EEs. While some combinations of settings and speakers are more frequently evoked when EEs are contested, there are other combinations that appear more commonly when EEs are normalized or not contested. We present the findings 
below and explore implications in the Discussion and Conclusion.

Settings: When describing the events relating to the cases, journalists tended to select one of six settings as described in Table 3.

Table 3. Settings Evoked in the Discourse of Elected Executions

\begin{tabular}{|c|c|c|c|c|}
\hline Settings & Description & Proportion & $\begin{array}{l}\text { Problematic? } \\
\text { Yes }\end{array}$ & $\begin{array}{l}\text { Problematic? } \\
\text { No }\end{array}$ \\
\hline Scene of Crime & $\begin{array}{l}\text { Occurring in the past, relating the de- } \\
\text { tails of the crime. }\end{array}$ & $9.1 \%(68)$ & $31 \%(21)$ & $69 \%(47)$ \\
\hline Courtroom & $\begin{array}{l}\text { Legal proceedings relevant to the specif- } \\
\text { ic case, legal arguments occurring in the } \\
\text { judges' chambers, courtrooms, and other } \\
\text { legal arenas. }\end{array}$ & $34.0 \%(225)$ & $54 \%(138)$ & $46 \%(117)$ \\
\hline Prison & $\begin{array}{l}\text { Occurring within the correctional set- } \\
\text { ting, not involving the final preparations } \\
\text { for the execution. }\end{array}$ & $9.1 \%(68)$ & $47 \%(32)$ & $53 \%(36)$ \\
\hline Governor's Office & $\begin{array}{l}\text { In the Governor's office, or in settings } \\
\text { where the governor acts with direct } \\
\text { authority. }\end{array}$ & $7.1 \%(53)$ & $58 \%(31)$ & $42 \%(22)$ \\
\hline Death Chamber & $\begin{array}{l}\text { The immediate temporal/physical } \\
\text { preparations for execution, including } \\
\text { moving to the final holding cell, last } \\
\text { meal, last rites, final words, and the } \\
\text { actual execution. }\end{array}$ & $27.5 \%(206)$ & $31 \%(64)$ & $69 \%(142)$ \\
\hline Outside Prison & $\begin{array}{l}\text { Protests or other actions occurring } \\
\text { immediately outside the prison. }\end{array}$ & $2.5 \%(19)$ & $63 \%(12)$ & $31 \%(7)$ \\
\hline Other & $\begin{array}{l}\text { Any article not about specific details of } \\
\text { the case, legal procedures not related to } \\
\text { the specific inmate, discussion of some } \\
\text { aspect not related to elected executions, } \\
\text { and meta-debates, such as a discussion } \\
\text { about capital punishment in general or } \\
\text { other social issues. }\end{array}$ & $10.7 \%(80)$ & $54 \%(43)$ & $46 \%(37)$ \\
\hline
\end{tabular}

Those settings where the largest proportion of articles normalized EEs were the scene of the crime and the death chamber, both of which presented EEs as non-problematic $69 \%$ of the time. The settings most likely to be selected when EEs were contested were the governor's office (58\% contested) and outside of the prison (63\% contested).

Speakers: When selecting speakers to serve as cultural authorities either in the form of direct quotes or paraphrased statements, journalists drew from a broad cast of characters, as described in Table 4.

Table 4. Speakers Evoked in the Discourse of Elected Executions

\begin{tabular}{|l|l|l|l|l|}
\hline Speakers & Description & Frequency & \multicolumn{1}{|c|}{$\begin{array}{c}\text { Problematic? } \\
\text { Yes }\end{array}$} & $\begin{array}{c}\text { Problematic? } \\
\text { No }\end{array}$ \\
\hline Judge & $\begin{array}{l}\text { Any judge relevant to } \\
\text { decisions in the case } \\
\text { including appeals court } \\
\text { and the Supreme Court. }\end{array}$ & $21.4 \%(170)$ & $45 \%(77)$ & $55 \%(93)$ \\
\hline
\end{tabular}




\begin{tabular}{|c|c|c|c|c|}
\hline Defense Attorney & $\begin{array}{l}\text { Those directly associat- } \\
\text { ed with the case. States } \\
\text { within the text that this } \\
\text { individual is working as } \\
\text { a defense attorney for } \\
\text { the inmate. }\end{array}$ & $24.4 \%(194)$ & $46 \%(89)$ & $(54 \%)(105)$ \\
\hline Prosecutors & $\begin{array}{l}\text { Those directly associat- } \\
\text { ed with prosecuting the } \\
\text { case at any phase. }\end{array}$ & $27.0 \%(214)$ & $39 \%(84)$ & $61 \%(130)$ \\
\hline Other Legal & $\begin{array}{l}\text { Other attorneys and } \\
\text { judges who are not } \\
\text { responsible for the } \\
\text { handling of the case in } \\
\text { question or represent } \\
\text { a party other than the } \\
\text { inmate or the state who } \\
\text { is directly involved in } \\
\text { the case. }\end{array}$ & $28.5 \%(226)$ & $60 \%(131)$ & $42 \%(95)$ \\
\hline Inmate & $\begin{array}{l}\text { The inmate who is in- } \\
\text { cluded in the sample. }\end{array}$ & $77.6 \%(616)$ & $43 \%(266)$ & $57 \%(350)$ \\
\hline Inmate's Family & $\begin{array}{l}\text { Any person who is } \\
\text { intimately acquainted } \\
\text { with the condemned. } \\
\text { Includes childhood } \\
\text { friends, parents, sib- } \\
\text { lings, children, spouses, } \\
\text { current friends, girl- } \\
\text { friends/wives they met } \\
\text { while in prison. }\end{array}$ & $15.5 \%(123)$ & $46 \%(57)$ & $54 \%(66)$ \\
\hline Victim's Family & $\begin{array}{l}\text { Any person who is inti- } \\
\text { mately acquainted with } \\
\text { the victim(s). Includes } \\
\text { childhood friends, par- } \\
\text { ents, siblings, spouses, } \\
\text { children, and current } \\
\text { friends. }\end{array}$ & $19.1 \%(152)$ & $42 \%(64)$ & $58 \%(88)$ \\
\hline Law Enforcement & $\begin{array}{l}\text { Any law enforcement } \\
\text { agent, including mar- } \\
\text { shals, sheriffs, police, } \\
\text { including those who } \\
\text { assisted in the arrest, } \\
\text { transportation, or pro- } \\
\text { tection of the inmate. }\end{array}$ & $5.2 \%(41)$ & $63 \%(26)$ & $37 \%(15)$ \\
\hline Dept. of Corrections & $\begin{array}{l}\text { Any representative of a } \\
\text { state or local correc- } \\
\text { tional department, in- } \\
\text { cluding wardens, prison } \\
\text { spokespersons, guards, } \\
\text { and parole boards. }\end{array}$ & $24.8 \%(197)$ & $47 \%(92)$ & $53 \%(105)$ \\
\hline $\begin{array}{l}\text { Mental Health Profes- } \\
\text { sional }\end{array}$ & $\begin{array}{l}\text { Psychologists, social } \\
\text { workers, and psychia- } \\
\text { trists. }\end{array}$ & $11.8 \%(94)$ & $67 \%(63)$ & $33 \%(31)$ \\
\hline Activists & $\begin{array}{l}\text { Any group/individual } \\
\text { who, out of personal/ } \\
\text { political/social convic- } \\
\text { tion becomes involved } \\
\text { in speaking about this } \\
\text { particular inmate or } \\
\text { their situation; }\end{array}$ & $23.4 \%(186)$ & $68 \%(127)$ & $32 \%(59)$ \\
\hline
\end{tabular}




\begin{tabular}{|c|c|c|c|c|}
\hline Religious Figures & $\begin{array}{l}\text { Any official of a church. } \\
\text { Nuns, ministers, and } \\
\text { reverends are included. } \\
\text { Is not required to have } \\
\text { had contact with the } \\
\text { inmate. }\end{array}$ & $8.1 \%(64)$ & $70 \%(45)$ & $30 \%(19)$ \\
\hline Media & $\begin{array}{l}\text { Those working in } \\
\text { news or entertainment } \\
\text { media, other than the } \\
\text { reporter who authored } \\
\text { the article. }\end{array}$ & $2.8 \%(22)$ & $73 \% 16$ & $27 \% 6$ \\
\hline Politicians & $\begin{array}{l}\text { Includes everyone from } \\
\text { the county commis- } \\
\text { sioners to the President } \\
\text { of the US. However, } \\
\text { Governors are a special } \\
\text { class of speakers. }\end{array}$ & $3.7 \%(29)$ & $52 \%(15)$ & $48 \%(14)$ \\
\hline Governors & $\begin{array}{l}\text { The governor of the } \\
\text { state in which the exe- } \\
\text { cution is taking place. }\end{array}$ & $25.2 \%(200)$ & $65 \%(129)$ & $35 \%(71)$ \\
\hline Other & $\begin{array}{l}\text { Any other speaker not } \\
\text { previously defined. }\end{array}$ & $0.6 \%(5)$ & $60 \%(3)$ & $40 \%(2)$ \\
\hline
\end{tabular}

While no category of speaker appeared exclusively in either contested or uncontested articles, there were speakers who more commonly appeared when EEs were contested and vice versa. The characters who are evoked most commonly in articles that normalized EEs include prosecutors (61\% normalized), victim's families (58\% normalized), and the inmate (57\% normalized). In comparison, those speakers who appear in more articles where elected executions are contested include religious figures (70\% contested), activists $(68 \%$ contested), mental health professionals ( $67 \%$ contested), governors (65\% contested), and law enforcement $(63 \%$ contested).

\section{The Drama of Elected Executions: A Play in Three Acts}

We found that journalists had a consistent way of narrativizing EEs which revolved around six locations or scenes. Each scene mobilized a different cast of characters who were selected by journalists to comment on the issue. In this way, journalists were able to present the specific events of the case and discuss the broader phenomenon of EEs. In this section, we identify the scenes in the drama of EEs. We highlight that certain locations and speakers are more (or less) likely to be evoked when EEs are described as problematic (or non-problematic). When viewed dramaturgically, speakers and scenes combine to evoke a theater depicting specific settings where prescribed characters appear on cue.

Act I, Scene 1, The Scene of the Crime: When an article is set at the scene of the crime, EEs are overwhelmingly normalized or treated as non-problematic. Only $31 \%$ of all the articles set at the scene of the crime contest EEs (see Table 3). As indicated in Table 5, the inmate is the dominant character in this setting regardless of whether the overall frame was one of contestation or non-contestation.

Table 5. Scene I, Act 1, Scene of the Crime

\begin{tabular}{|c|c|c|c|}
\hline \multicolumn{4}{|c|}{ Speakers at the Scene of the Crime } \\
\hline \multicolumn{2}{|l|}{ Contesting EEs } & \multicolumn{2}{|l|}{ Not Contesting EEs } \\
\hline Inmate & $90 \%(19)$ & Inmate & $89 \%(42)$ \\
\hline Dept. of Corrections & $76 \%(16)$ & Prosecutors & $34 \%(16)$ \\
\hline Defense/Other Legal & $38 \%(8)$ & Dept. of Corrections/Defense & $28 \%(13)$ \\
\hline
\end{tabular}


This is perhaps not surprising given the inmate's role as primary antagonist throughout (most of) the EE process and the protagonist's (victim's) necessary absence from the stage. The speakers who enter into this setting differ by whether or not they serve to legitimize the inmate's decision to hasten execution. Spokespersons from the Department of Corrections and attorneys fighting the execution are present in articles that contest the elected execution, while prosecutors and defense attorneys, along with the inmate, are present when articles normalize the inmate's decision to halt appeals. For example, an inmate in Florida told the judge that he wished for his "execution to come swift and unhampered" (Inmate Glen Ocha quoted in "Woman's killer scheduled for execution Tuesday: Wants no appeals," Associated Press, April 4, 2005). When an inmate initiates the process of ending his or her appeals after the sentence of death has been handed down, all other actors who participate in this pre-incarceration phase are presented as beginning their own process of acquiescing to the inmate's decision. One inmate's attorney told the AP that he believed his client looked at his execution "as peace" (Attorney Pat McCann quoted in "Killer executed in death of prostitute," Associated Press, June 7, 2005).

Act I, Scene 2, The Courtroom: The second scene plays out in the courtroom, where an inmate's decision to halt appeals is moderately contested (54\% of articles problematize EEs). Typically the courtroom setting encompasses the appeals process and the competency hearing if one was requested, and a number of characters appear as indicated in Table 6.

Table 6. Scene I, Act 2, Courtroom

\begin{tabular}{|l|l|l|l|}
\hline \multicolumn{2}{|l|}{ Speakers in the Courtroom } \\
\hline Contesting EEs & Not Contesting EEs \\
\hline Inmate & $86 \%(118)$ & Inmate & $91 \%(106)$ \\
\hline Other Legal & $48 \%(66)$ & Judge & $43 \%(60)$ \\
\hline Judge & $43 \%(60)$ & Defense & $33 \%(39)$ \\
\hline
\end{tabular}

At this phase in the judicial proceedings, the inmate is presented as staunchly opposed to anyone fighting his or her choice to halt appeals and only appears in the problematic courtroom articles because he or she factors so prominently into this setting. Other legal personnel appear because they are attorneys who no longer act on the inmate's bequest but in the interest of the family or on their own convictions. For example, an attorney from Arizona (representing a Texas inmate) told the reporter that "when you have an inmate who wants to commit state assisted suicide, it makes [a defense] all the more difficult. There is a presumption that the individual is able to make a competent decision. It is very tough to overcome" (Attorney Natman Schaye, lawyer and co-chairman of the death penalty committee of the National Association of Criminal Defense Lawyers, quoted in 'Johnson reiterates he won't stop Clark execution," Associated Press, October 31, 2002).

In this scene, judges are called upon to make a ruling about the inmate's decision and they are typically presented as even-handed professionals whose response to EEs is based on adherence to judicial precedent. One judge told defense attorneys "evidence showing that an inmate's decision is the product of a mental disease does not show that he lacks the capacity to make a rational choice" (Judge Pamela Rymer quoted in "Appeals court says Nevada inmate can drop appeals, be executed," Associated Press, July 30, 2004). Further, the Florida Supreme Court wrote in a decision in 2002 that "these cases are about the right of SELF-DETERMINATION and FREEDOM to make fundamental choices affecting one's life"(Florida Supreme Court, "Court: Death row inmate has right to choose death," Associated Press, April 3, 2002; emphasis in original). The numbers of articles that contest or do not contest EEs in which a judge plays a role are equal. In those courtroom settings where EEs are not contested, most of the actors normalize the decision through arguments about the rights of inmates, the outcome of their contested competence hearing, or the ongoing danger they pose to society. To illustrate, a prosecutor in Texas was quoted as saying, "this inmate is a horrible danger to society and he will remain so. He's a sociopath, an absolute sociopath, but sane" (Prosecutor Susan Reed, "Judge refuses to allow hearing for convict who wants to die," Associated Press, March 9, 1985).

While not dominant in this setting, mental health professionals add legitimacy to the arguments on both sides of the legal debate over EEs. One psychiatrist in Nevada told the court that the inmate "does have the capacity to 
appreciate his position and make a rational choice" (Nevada Supreme Court quoting a psychiatrist's report, "Nevada court lets condemned man withdraw appeal," Associated Press, March 12, 2004). The same reference to mental competence can be used to contest elected executions. A psychologist told a New Mexico judge that the inmate's "current conditions of confinement have so beaten him down that he doesn't want to live anymore" (Brian Pori quoting a psychiatrist's report, "Prosecution, defense, dispute death row inmate's alleged brain damage," Associated Press, April 30, 2001). When defense attorneys appear they act as one adhering to the wishes of their client(s). A defense attorney in Florida was quoted as saying her client "was very coherent. He was cogent. He instructed me not to interfere with his execution" (Attorney Baya Harrison quoted in "Gov. Bush lifts stay for condemned man, execution set Wednesday," Associated Press, October 1, 2002).

Act II, Scene 1, The Prison: Much like the courtroom setting described above, the language presented in the prison setting is somewhat ambivalent with regard to EEs - 53\% of articles present the phenomenon as routine or non-problematic while $47 \%$ contest it. The dominant figure, the inmate, acts to both contest and normalize the decision to elect execution (see Table 7).

Table 7. Scene II, Act 1, Prison

\begin{tabular}{|l|l|l|l|}
\hline \multicolumn{2}{|l|}{ Speakers in the Prison } & Not Contesting EEs \\
\hline Contesting EEs & $84 \%(27)$ & Inmate & $94 \%(34)$ \\
\hline Inmate & $50 \%(16)$ & Prosecutor & $44 \%(16)$ \\
\hline Dept. of Corrections & $30 \%(11)$ & $\begin{array}{l}\text { Defense \& Dept. of } \\
\text { Corrections }\end{array}$ & $36 \% 139)$ \\
\hline Governor & \multicolumn{3}{|l|}{} \\
\hline
\end{tabular}

An inmate in Nevada told the AP that "he did not believe he had anything to win so he would just be prolonging this and in the end he would still have to do it" (Reporter quoting inmate Jesse Bishop, "Domestic news," Associated Press, October 17, 1979). Prosecutors tend to cooperate with inmates when the event is normalized. For example, one prosecutor stated that many volunteers choose this mode of execution because "they feel it will make the victim's family feel better because they put the family through hell and they understand that now" (District Attorney Shirley quoted in "Dying drug addict allowing executions to move forward," September 21, 1999). An inmate echoed this belief when he reported that he "is the type of individual to face up to his responsibility and his mistakes" (Inmate James Porter quoted in "U.S. killer who sought death penalty awaits execution," January 3, 2005).

Act II, Scene 2, The Governor's Office: Articles set in the governor's office comprise the second largest proportion of articles that contest EEs. In fact, this is the setting where those actors who have a moral, political or social argument against EEs make their entrance, as detailed in Table 8.

Table 8. Scene II, Act 2, Governor's Office

\begin{tabular}{|c|c|c|c|}
\hline \multicolumn{4}{|c|}{ Speakers in the Governor's Office } \\
\hline \multicolumn{2}{|c|}{ Contesting EEs } & \multicolumn{2}{|c|}{ Not Contesting EEs } \\
\hline Governor & $87 \%(27)$ & Governor & $86 \%(19)$ \\
\hline Activists & $61 \%(19)$ & Inmate & $55 \%(12)$ \\
\hline Other Legal & $58 \%(18)$ & Activists & $36 \%(8)$ \\
\hline
\end{tabular}

Oftentimes, these actors have had no personal association with the inmate, and their contestations of EEs are based on impersonal (ideological) arguments rather the idiosyncratic arguments that typify the courtroom setting. One activist expressed his concerns for the social ramifications of allowing inmates to elect their executions, stating that "if this first volunteer in Ohio was put to death, other executions would follow. The first domino is key" (Professor Christo Lassiter quoted in "Minister says Berry ready to die," Associated Press, March 4, 2005). When 
EEs are normalized in the governor's office setting, actors frequently evoke the victim's family in order to justify the event, recounting the horrific nature of the crime(s) committed and the outcome of competence hearings. For example, the Governor of Florida told the AP that the "crime was very heinous... after a thorough and thoughtful process, this is the end of it" (Jacob DiPietre, spokesman for Governor Jeb Bush quoted in "Gov. Bush signs death warrant for Osceola county killer," Associated Press, March 4, 2005). Referring to another execution, Governor Bush explained that he has a "duty to have sympathy for the victims" (Governor Jeb Bush quoted in "Florida inmate who dropped appeals executed for 1999 slaying," Associated Press, April 5, 2005). In this particular setting, the inmate is typically presented as almost pleading with the governor to leave well enough alone and allow the execution to continue. For example, one inmate told the press that she was tired of the governor using her execution as fodder for his reelection campaign and to just sign the death warrant (Inmate Aileen Wuornos, "Florida Gov. Bush orders one of first known U.S. female serial killers executed next month," Associated Press, September 3, 2002).

Act III, Scene 1, The Death Chamber: Articles where the death chamber is the setting are the largest proportion of articles (66\%) in which EEs are normalized. At this phase in the drama, all the cards seem to be in the inmate's hands. All other actors will respond only to cues from him or her, as detailed in Table 9.

Table 9. Scene III, Act 1, Death Chamber

\begin{tabular}{|l|l|l|l|}
\hline \multicolumn{2}{|l|}{ Speakers in the Death Chamber } & Not Contesting EEs \\
\hline Contesting EEs & $97 \%(62)$ & Inmate & $91 \%(129)$ \\
\hline Inmate & $48 \%(31)$ & Dept. of Corrections & $55 \%(68)$ \\
\hline Dept. of Corrections & $47 \%(30)$ & $\begin{array}{l}\text { Prosecutors and Victim's } \\
\text { Family }\end{array}$ & $29 \%(41)$ \\
\hline Governor & & \\
\hline
\end{tabular}

A department of Corrections representative reported that if the inmate gave the word, attorneys were standing by to file necessary papers to stop the execution, but that the inmate had not called upon them to do so (State Prison Director Charles Wolff Jr. quoted in "Domestic news," Associated Press, October 20, 1979). The victim's family, along with prosecutors, enters the stage to make the case that this execution is for the best and now the victims can find peace. For example, one victim's mother in New Mexico told the AP that after 15 years of being at trials and court hearings, she was not going to miss the day to see justice for her daughter (Colleen Gore quoted in "Dena Lynn's father doesn't believe Clark will be executed," Associated Press, July 31, 2001).

Act III, Scene 2, Outside the Prison: The final scene occurs in the space directly outside of the prison on the days leading up to the execution or on the day itself. This setting figures most strongly among those articles contesting EEs, as described in Table 10.

Table 10. Scene III, Act 2, Outside the Prison

\begin{tabular}{|l|l|l|l|}
\hline \multicolumn{2}{|l|}{ Speakers Outside the Prison } & Not Contesting EEs \\
\hline Contesting EEs & $100 \%(12)$ & Activists & $71 \%(5)$ \\
\hline Activists & $83 \%(10)$ & Inmate & $57 \%(4)$ \\
\hline Religious Figures & $58 \%(7)$ & $\begin{array}{l}\text { Religious Figures and Prose- } \\
\text { cutors }\end{array}$ & $43 \%(3)$ \\
\hline Inmate & & \\
\hline
\end{tabular}

Like the governor's office, this setting is populated by actors who have moral or political concerns about EEs or with capital punishment in general, and who speak against the broad social effects of these events. Frequently, such a statement involves a criticism of the US criminal justice system. The former governor of New Mexico told the crowd outside of the prison that this execution "is not about one man at all. This is a battle for the heart and soul of New Mexico" (Former New Mexico Governor Toney Anaya quoted in "Death penalty opponents, supporters hold vigils 
as Clark dies," Associated Press, November 6, 2001). Those actors appearing in articles where EEs are normalized in this setting are mobilized to support the inmate's choice or support the victims of violent crime. One protester told the reporter that she was here to "support the family. It has nothing to do with the death penalty" (Activist Pam McCoy quoted in "Protesters gather to decry Nevada execution," Associated Press, April 27, 2006).

\section{Discussion}

To emphasize, our study examines speakers' presence in journalistic settings that normalize or contest EEs. Our data does not systematically capture speakers' precise arguments for or against EEs. We know each scene and which characters populate each scene, but not always whether those characters oppose or support EEs. Returning to Benford and Hunt's (1992) discussion of the conception of power in the dramaturgy of social movements, and Carragee and Roefs' (2004) discussion of power in framing research, what can we infer from our study about larger cultural authority over chosen executions? In terms of sheer quantity of time on-stage, the dominance of the inmate throughout this drama is perhaps no surprise, for as Haines points out, "The script of the ideal execution naturally contains a role for the person being put to death" (1992: 129; see also Conquergood 2002: 362). The dramaturgical dominance of the inmate would seem to grant him or her cultural (discursive) authority over his or her own fate, thus supporting the larger volunteering/choice frame of EEs that is sponsored by the pro-capital punishment community in the US (Harrington, 2000, 2004; Muschert et al. 2009). But the ambiguity of the inmate's role, on-stage nearly as often in scenes that contest EEs as in those that normalize them, muddies the claim. So too does the fact that inmates are less likely to be on-stage in two of the most overtly "political" settings in this drama - the governor's office, where final decisions about pardons or clemency might occur, and outside the prison, where pro- and anti-capital punishment activists gather to express their political and moral beliefs. Inmates are rarely mobilized, in other words, in settings where larger macro-level discussions about the politics, law, and ethics of EEs might reasonably occur. Their presence in this drama is to represent the level of the personal, the individual (see below).

Consider, as well, the relatively minimal presence of defense attorneys in this dramatic performance, the nearcomplete absence of the audience (general public), and the key settings chosen by journalists when EEs are both normalized and contested. Defense attorneys appear in three of the six scenes (scene of the crime, courtroom, and prison) and are the least active character (or least dominant speaker) on-stage in each scene; moreover, two of their three scenes (courtroom and prison) serve to normalize rather than contest the inmate's chosen action. Given that defense attorneys are formally charged with protecting their client's best interests, and in EEs are placed in the odd position of deciding whether death by execution serves those interests, one might expect attorneys to have a more prominent role in the cast. This is especially true for the approximately 200-member group of anti-death penalty cause lawyers in the US who specialize in representing death row inmates in post-conviction appeals and who have unusually close relationships with their clients (Harrington 2000; Sarat 1998). How can we make sense of their minimal role? Since attorneys' professional guidelines do not lay out their formal duties in the context of EEs (Harrington 2000), their behavior is perhaps less predictable - that is, from a journalist's perspective is less predictably tied to a particular scene or setting - than that of other characters such as state governors, law enforcement officials and/or death penalty activists. However, we also might question whether defense attorneys' lack of on-stage presence and their evocation in scenes that normalize EEs may help reassure spectators (readers) that the subsequent execution is appropriate (or in Haines' [1992] terminology, “clean"). Rather than a co-starring role in which s/he actively thwarts his or her client's wishes, defense counsel is presented as offering implicit support by fading into the background. As one defense attorney described, in cases of EEs '[e]verybody is doing the 'right' thing together" - including the inmate - and this "may give the public a certain sense of absolution for the death penalty itself" (quoted in Harrington 2004: 1133). The absence of defense counsel in this particular drama thus provides further support for the argument that the US news media helps normalize EEs (and thus legitimize capital punishment) through its framing practices (Muschert et al. 2009).

We also note the virtual absence of the general public (aside from family members of both inmate and victim) in the dramaturgy of EEs. Foucault (1977) argued that in open (publicized) executions the main character is the audience - the general public has to know an execution has taken place for it to be effective. Miller and Hunt agree, stating "the audience is still the most important character in the current system of punishment and [. . .] executions are still spectacles. The news media has replaced the scaffold and the crowd of observers is larger than ever, just 
hidden from view" (2008: 190). In that light, the absence of the audience in reportage of EEs is somewhat baffling - the dramatic point is incomplete or obscured - because unlike with routine (non-consensual) executions, we have no way to infer how the audience reacts to the drama of EEs. While there are frequent national polls assessing public support of the death penalty, thus allowing press reports of most executions to be read in the context of broader "known" patterns of audience response, there have been no empirical studies to date of laypersons' understanding of executions that are chosen. While our prior study (Muschert et al. 2009) speculated about how news framing of EEs might impact public opinion, there is no systematic data that sheds light on this issue. In this particular drama, then, journalists' inclusion of the audience-as-speaker could offer a more comprehensive portrait of the phenomenon of EEs than is currently available (even though speaker quotes would still be selected by journalists, etc.).

Finally, consider the setting/speaker combinations that dominate when EEs are normalized versus when they are contested. In short, news stories set at the scene of the crime and the death chamber are most likely to normalize EEs and tend to be populated by figures most intimately familiar with the crime and its consequences at the individual- or micro-level (e.g. inmate, victim's family). In contrast, settings in which EEs tend to be contested (Governor's office, outside the prison) are populated with a wider range of characters less intimately connected with the inmate and victim(s), who are instead discursively associated with more macro-level political and/or ideological perspectives on capital punishment (e.g. gubernatorial staff, activists, religious spokespersons). Earlier we summarized literature pointing to a range of political influences, both formal and informal, that influence the death penalty and shape the roles played by all participants in the process (Bonnie 1990; Harrington 2004). We find it interesting that journalistic practices appear to articulate and/or highlight political aspects when contesting EEs (through quoting a Governor or self-defined activist, for example) while normalizing EEs through de-politicizing strategies (through focusing on a family's sense of closure or an inmate's last words, for example). In the context of socio-legal debates about EEs, this provides support for scholars who argue that EEs are an "intimate" decision best left to the inmate (e.g. K. L. Johnson 1981), as well as for those who reject EEs due to the legal, legislative, and administrative challenges it presents (e.g. Dieter 1990). Journalistic practices, then, correspond with scholarly debates about EEs.

\section{Conclusion}

Writing in a very different context, anthropologist Davis-Floyd (1997) documents the ritualistic practices that transformed childbirth during the 20th century in the US, shifting it from a "natural" process into one thoroughly mediated and moderated by science, technology, and medical professionals. As cultural authority over the birthing process was wrested from the woman giving birth to the techno-medical establishment, (female-dominated) reproduction was transformed into (male-dominated) production. The dramaturgical analysis undertaken here suggests a more ambiguous transformation, less absolute though arguably as dramatic. As we noted earlier, the socio-legal discourse that surrounds EEs uses a dominant discourse of volunteering to refer to inmates' desire to hasten appeals, a terminology which seems to transform the antagonist of this drama - the criminal sentenced to death - into a protagonist instead, nobly accepting his or her punishment. Our own prior study offered support for this perspective, as US print journalists' adoption of a dominant choice frame upheld the notion of the inmate as agentic participant in the execution process (Muschert et al. 2009). Our more nuanced analysis of journalistic practices undertaken here, however, suggests a more indefinite positioning of the inmate - still the lead character but one whose motives and agency are unclear and whose staunchest ally (defense counsel) plays but a minor role.

Moreover, the overall journalistic stance on EEs remains uncertain. The scenes taking place at the scene of the crime and the death chamber offer the same level of strong support for the non-problematic nature of EEs (69\% unproblematic, 31\% problematic), with scenes taking place in the courtroom, prison, and governor's office offering indefinite readings on the phenomenon. Were the play to end after scene 5, the weight of the argument would suggest that inmates' decisions to waive appeals are laudable and should be respected (i.e. the pro-capital punishment position). But the final scene outside the courtroom throws a twist, with only $31 \%$ of articles taking a non-problematic stance on EEs. Greer writes, "Like crime narratives more generally, execution narratives are structured and inflected in various ways that encourage 'seeing' through the eyes of the state and [...] through the eyes of victims or their loved ones" (2006: 97). Similarly, Miller and Hunt (2008) conclude their dramaturgical analysis of non-consensual execution news stories by explaining that the "construction of the majority of execution stories implies that the death sentence is a proper closure to a string of criminal and legal events" (p. 208). It perhaps 
requires an expert in theatre to know best how to interpret surprise endings and their likely impact on audience members. Suffice it to say that the journalistic construction of cultural authority over EEs is indefinite - and given the link between particular frames and master frames (Van Gorp 2007), our findings seem to speak to growing ambiguity about capital punishment in the US.

\section{Endnotes}

1: Questions of voluntariness and competence are relevant since the US constitution prevents the execution of the mentally incompetent (Ford v. Wainwright, 1986), and since many question whether a "rational" person would ever elect his or her own death. For example, in a recent study Blume (2005) documents linkages between EEs and schizophrenia, depression, post-traumatic stress disorder and suicidal ideation and/or attempts. For a discussion of EEs, mental competence, and end-oflife decision-making see Harrington (2004).

\section{References}

Altheide, David. 1987. "Ethnographic Content Analysis." Qualitative Sociology. 10: 65-77.

Altheide, David. 1996. Qualitative Media Analysis. Thousand Oaks, CA: Sage.

Associated Press. 2008. "The Essential Global News Network." Retrieved July 1, 2008, from Associated Press Web site: http:// ap.org/

Associated Press. 2009, November 14. "Prominent State Challenges to Lethal Injection.” Retrieved November 17, 2009 from http://www.daytondailynews.com

Benford, Robert D. and Scott A. Hunt. 1992. "Dramaturgy and Social Movements: The Social Construction and Communication of Power." Sociological Inquiry. 62(1): 36-55.

Blume, John. 2005. “Killing the Willing: 'Volunteers', Suicide and Competency.” Michigan Law Review. 103: 939-1009.

Bonnie, R. J. 1990. "Dilemmas in Administering the Death Penalty: Conscientious Abstention, Professional Ethics, and the Needs of the Legal System." Law and Human Behavior. 14: 67-90.

Carragee, Kevin M. and Wim Roefs. 2004. "The Neglect of Power in Recent Framing Research." Journal of Communication. 54(2): 214-233.
Chyi, Hsiang Iris and Maxwell McCombs. 2004. "Media Salience and the Process of Framing: Coverage of the Columbine School Shootings." Journalism \& Mass Communication Quarterly. 81(1): 22-35.

Coe, Kevin, David Domke, Erica S. Graham, Sue Lockett John and Victor W. Pickard. 2004. "No

Shades of Gray: The Binary Discourse of George W. Bush and an Echoing Press." Journal of Communication. 54(2): 234-252.

Conquergood, Dwight. 2002. "Lethal Theatre: Performance, Punishment, and the Death Penalty." Theatre Journal. 54(3): 339-367.

Culver, John. 1999. "Capital Punishment Politics and Policies in the States, 1977-1997." Crime, Law \& Social Change. 32: 287-300.

Davis-Floyd, Robbie E. 1997. "Gender and Ritual: Giving Birth the American way."Pp. 403-415 in Gender in Cross-Cultural Perspective, edition 2, edited by C. B. Brattell and C. F. Sargent. Upper Saddle River, NJ: Prentice Hall.

Dieter, Richard. 2009. The Death Penalty in 2009: Year End Report. Washington, D.C.: Death Penalty Information Center.

Dieter, Richard. 1996. "Killing for Votes: The Dangers of Politicizing the Death Penalty Process." Retrieved May 3, 2007 from http://www.deathpenaltyinfo.org/article. php?scid $=45 \&$ did $=260$ 
Dieter, Richard. 1990. "Ethical Choices for Attorneys Whose Clients Elect Execution." Georgetown Journal of Legal Ethics. 3: 799-820.

Eglin, Peter. 1980. "Culture as Method: Location as an Interactional Device.” Journal of Pragmatics. 4:121-135.

Eglin, Peter and Stephen Hester. 2003. The Montreal Massacre: A Story of Membership Categorization Analysis. Waterloo, Ontario: Wilfrid Laurier University Press.

Foucault, Michel. 1977. Discipline and Punish: The Birth of the Prison. New York: Vintage Books.

Glaser, Barney G. and Anselm Strauss. 1967. The Discovery of Grounded Theory: Strategies for Qualitative Research. Chicago: Aldine.

Goffman, Erving. 1959. The Presentation of Self in Everyday Life. Garden City, NY: Doubleday-Anchor.

Greer, C. 2006. "Delivering Death: Capital Punishment, Botched Executions and the American News Media." Pp. 84-102 in Captured by the Media: Prison Discourse in Popular Culture, edited by P. Mason. Portland, OR: Willan.

Grinberg, Emanuella. 2009. "Budget Concerns Force States to Reconsider the Death Penalty." Retrieved March 2, 2009 from http://www.cnn.com

Haines, Herbert. 1992. "Flawed Executions, the Anti-Death Penalty Movement, and the Politics of Capital Punishment." Social Problems. 39: 125-138.

Harrington, C. Lee. 2004. "Mental Competence and End-of-Life Decision-Making: Death Row Volunteering and Euthanasia." Journal of Health Politics, Policy \& Law. 29: 1109-1151.

Harrington, C. Lee. 2000. "A Community Divided: Defense Attorneys and the Ethics of Death Row Volunteering." Law \& Social Inquiry. 25: 849-881.

Jacobs, David and Stephanie L. Kent. 2007. “The Determinants of Executions Since 1951: How Politics, Protests, Public Opinion, and Social Divisions Shape Capital Punishment." Social Problems. 54(3): 297-318.

Jacobs, David and Jason T. Carmichael. 2002. "The Political Sociology of the Death Penalty: A Pooled Time-Series Analysis." American Sociological Review. 67: 109-131.

Jacoby, J. E., E. F. Bronson, A. R. Wilczak, J. M. Mack, D. Stuter and Qiang Xu. 2008. "The Newsworthiness of Executions." Journal of Criminal Justice and Popular Culture. 15(2): 168-188.

Jewkes, Y. 2006. "Creating a Stir? Prisons, Popular Media and the Power to Reform." Pp. 137-153 in Captured by the Media: Prison Discourse in Popular Culture, edited by P. Mason. Portland, OR: Willan.

Johnson, K. L. 1981. “The Death Row Right to Die: Suicide or Intimate Decision?" Southern California Law Review. 54: 575-631.
Kovandzic, Tomislav V., Lynne M. Vieraitis, and Denise Paquette Boots. 2009. "Does the Death Penalty Save Lives? New Evidence from State Panel Data, 1977 to 2006." Criminology and Public Policy. 8(4): 803-843.

Kubik, Jeffrey D. and John R. Moran. 2003. "Lethal Elections: Gubernatorial Politics and the Timing of Executions."Journal of Law and Economics. 56: 1-25.

Langbein, Laura I. 1999. "Politics, Rules, and Death Row: Why States Eschew or Execute Executions." Social Science Quarterly. 80(4): 629-647.

Lipschultz, J. H. and M. L. Hilt. 1999. "Mass Media and the Death Penalty: Social Construction of Three Nebraska Executions." Journal of Broadcasting \& Electronic Media. 43: 236-253.

Lofland, J. 1975. “Open and Concealed Dramaturgic Strategies: The Case of the State Execution.” Urban Life. 4(3): 272-295.

Miller, Karen S. and Scott A. Hunt. 2008. "Exit Stage Left: A Dramaturgical Analysis of Media Accounts of Executions in America." Journal of Criminal Justice and Popular Culture. 15(2): 189-217.

Muschert, Glenn W., C. Lee Harrington and Heather R. Reece. 2009. "Elected Executions in the U.S. Print News Media." Criminal Justice Studies: A Critical Journal of Crime, Law and Society 22(3): 345-366.

Muschert, Glenn W. and Dawn Carr. 2006. "Media Salience and Frame Changing Across Events: Coverage of Nine School Shootings, 1997-2001." Journalism \& Mass Communication Quarterly. 83(4): 747-766.

Niven, D. 2004. “Southern Newspaper Coverage of Exonerations from Death Row." Journal of Criminal Justice and Popular Culture. 11: 20-31.

Nicholson, Robert A. and Steve Norwood. 2000. "The Quality of Forensic Psychological Assessment, Reports and Testimony: Acknowledging the Gap between Promise and Practice." Law and Human Behavior. 24: 9-44.

Sacks, Harvey. 1992. Lectures on Conversation, Vol. 1. Oxford, UK: Basil Blackwell.

Sarat, A. 2001. When the State Kills: Capital Punishment and the American Condition. Princeton, NJ and Oxford: Princeton University Press.

Sarat, A. 1998. "Between the (Presence of) Violence and the (Possibility of) Justice.” Pp. 317-346 in Cause Lawyering: Political Commitments and Professional Responsibilities, edited by A. Sarat and S. Scheingold. New York: Oxford University Press.

Scott, William A. 1955. "Reliability of Content Analysis: The Case of Nominal Scale Coding." Public Opinion Quarterly. 19: 321-325. 
Stack, S. 2004. "Publicized Executions and Homicide: A Quantitative Review of 385 Findings." Paper presented at the annual meetings of the American Sociological Association, San Francisco, California, August.

Strafer, R. G. 1983. "Volunteering for Execution: Competency, Voluntariness, and the Propriety of Third Party Intervention." Journal of Criminal Law and Criminology. 74: 860-912.

van Dijk, Teun A. 1988. News as Discourse. Hillsdale, NJ: Lawrence Erlbaum.
Van Gorp, Baldwin. 2007. "The Constructionist Approach to Faming: Bringing Culture Back In." Journal of Communication. 57: 60-78.

Wallace, D. H. 1992. "The Need to Commute the Death Sentence: Competency for Execution and Ethical Dilemmas for Mental Health Professionals." International Journal of Law and Psychiatry. 15: 317-337.

Wardle, C. and R. Gans-Boriskin. 2004. "Who Deserves to Die? Discussions of the Death Penalty on Primetime Television." Journal for Crime, Conflict and the Media. 1(3): 68-88. 